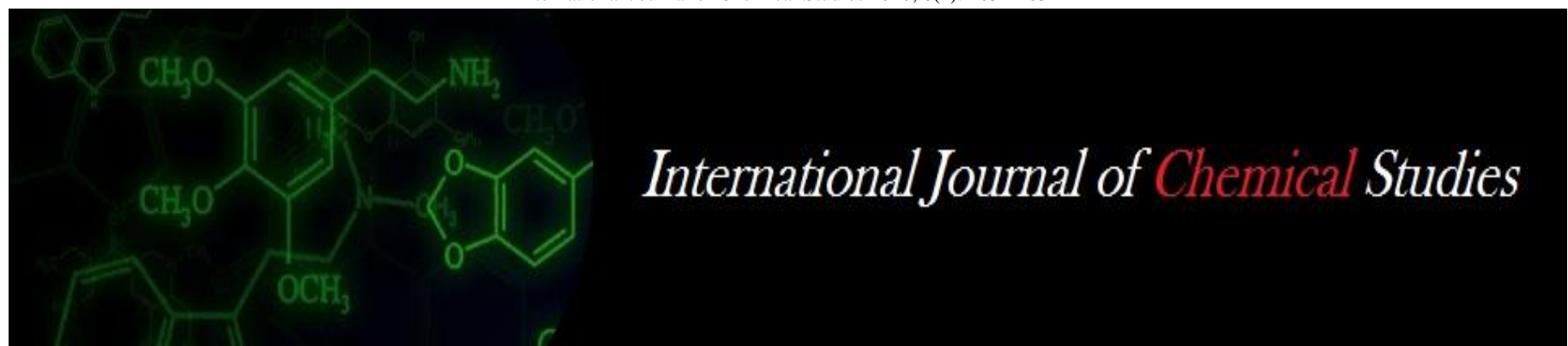

P-ISSN: 2349-8528

E-ISSN: 2321-4902

IJCS 2020; 8(1): 1052-1054

(C) 2020 IJCS

Received: 13-11-2019

Accepted: 16-12-2019

\section{Soumya Kulkarni}

Department of Soil Science and Agricultural Science, University of Agricultural Sciences,

Raichur, Karnataka, India

\section{Narayana Rao K}

Department of Soil Science and Agricultural Science, University of Agricultural Sciences,

Raichur, Karnataka, India

\section{Ravi MV}

Department of Soil Science and Agricultural Science, University of Agricultural Sciences,

Raichur, Karnataka, India

\section{Mahadeva Swamy}

Department of Soil Science and Agricultural Science, University of Agricultural Sciences,

Raichur, Karnataka, India
Corresponding Author: Soumya Kulkarni

Department of Soil Science and Agricultural Science, University of Agricultural Sciences,

Raichur, Karnataka, India

\section{Effect on soil biological properties as influenced by different nutrient management approaches under pigeonpea cultivation in Vertisol}

\author{
Soumya Kulkarni, Narayana Rao K, Ravi MV and Mahadeva Swamy
}

DOI: https://doi.org/10.22271/chemi.2020.v8.i1n.8391

\begin{abstract}
A study was conducted to know the effect of different nutrient management approaches along with FYM on soil biological properties in pigeonpea cultivation during 2016-17 and 2017-18 in farmer's field of Raichur district. The experiment was laid out in Randomized Block Design with three replications and ten treatments. The results revealed that, application of $150 \%$ RDF approach with FYM at 90 DAS and at harvest stage of pigeonpea significantly increased the beneficial microbial load of bacteria (37.08 and

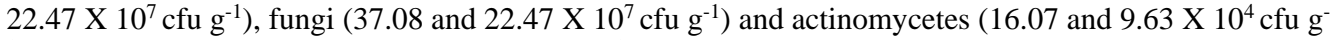
${ }^{1}$ ), microbial biomass ( 277 and $261 \mu \mathrm{g} \mathrm{CO}_{2}-\mathrm{C} \mathrm{g}^{-1}$ soil for $24 \mathrm{hrs}$ ) and enzyme activities of dehydrogenase (21.09 and $15.73 \mu \mathrm{g} \mathrm{TPF} \mathrm{g}^{-1}$ soil for $24 \mathrm{hrs}$ ), phosphatase (69.37 and $66.8 \mu \mathrm{g}$ PNP g ${ }^{-1}$ soil for $1 \mathrm{hr}$ ) and urease (170 and $161 \mu \mathrm{g} \mathrm{NH}_{4}-\mathrm{N} \mathrm{g}^{-1}$ soil for $2 \mathrm{hrs}$ ) in soil, respectively.
\end{abstract}

Keywords: Nutrient management, pigeonpea, RDF

\section{Introduction}

Leguminous crops are rich source of protein in vegetarian diet and play a significant role in preventing the widespread malnutrition in the country. Pigeonpea is a popular pulse crop of India and provides variety of protein rich vegetarian dishes for humans. Application of balanced fertilizer increases microbial load of bacteria, fungi and actinomycetes along with beneficial enzyme activities. It is the $5^{\text {th }}$ prominent pulse crop in the world and $2^{\text {nd }}$ in India after chick pea. In India, pigeonpea ranks second in both acreage (5.13 million ha) and production (4.23 million tonnes) among the pulses with average productivity of $824 \mathrm{~kg} \mathrm{ha}^{-1}$ (Anonymous 2015) ${ }^{[1]}$. It occupies an area of 0.77 mha with a production of $0.53 \mathrm{mt}$ with an average productivity of $596 \mathrm{~kg} \mathrm{ha}^{-1}$ in Karnataka (GOI, 2012).

Soil biological properties are regarded as soil quality indicators as they respond rapidly to environmental changes and these can be particularly useful for assessing soil fertility and quality in studies. The soil biological property responds very well to the inorganic and organic nutrient sources. Hence, the present study was undertaken to know the effect on soil biological properties as influenced by different nutrient management approaches in pigeonpea cultivation.

\section{Material and Methods}

An experiment was conducted at farmer's field of Raichur district. The dominant soil type was Vertisol meant with a clay texture containing $0.52 \%$ organic carbon and $\mathrm{pH}$ of 7.90 . The pigeonpea variety TS-3R was used. The experiment was laid out with randomised block design with three replications and ten treatments. Treatment groups consisted of $\mathrm{T}_{1}$ : Absolute control, $\mathrm{T}_{2}$ : Farmer practice, $\mathrm{T}_{3}$ : RDF (25:50:00 kg ha-1 as per POP), $\mathrm{T}_{4}: 150 \% \mathrm{RDF}, \mathrm{T}_{5}$ : Soil Test Laboratory Method, $\mathrm{T}_{6}$ : Soil Test based NPK $\pm 25 \%, \mathrm{~T}_{7}$ : Soil Test based $\mathrm{N} \pm 25 \%$ and $\mathrm{P}$ $\pm 50 \%, \mathrm{~T}_{8}$ : STCR Approach (Targeted yield of $15 \mathrm{q} \mathrm{ha}^{-1}$ ), $\mathrm{T}_{9}$ : STCR Approach (Targeted yield of $18 \mathrm{q} \mathrm{ha}^{-1}$ ) and $\mathrm{T}_{10}$ : STCR Approach (Targeted yield of $20 \mathrm{q} \mathrm{ha}^{-1}$ ). Well decomposed FYM containing $0.5 \% \mathrm{~N}, 0.2 \% \mathrm{P}_{2} \mathrm{O}_{5}$ and $0.5 \% \mathrm{~K}_{2} \mathrm{O}$ was applied 10 days prior to sowing as per treatments. Soil sample from each treatment plot were collected at 90 DAS and at harvest stage of pigeonpea and were immediately stored in polythene bags. The soil samples were preserved and stored at $5^{\circ} \mathrm{C}$ in a refrigerator until analysis. 
Theses samples were utilized for the assay of soil microbial load of bacteria, fungi and actinomycetes, soil biomass and soil enzyme activity. Methods employed for the determination of above parameters as follows:

Table 1: The show parameters and method

\begin{tabular}{|c|c|c|}
\hline Parameters & Method & Reference \\
\hline Microbial flora (Bacteria, Fungi and Actinomycetes) & Serial dilution and agar plate method & Pramer and Schmidt (1964) \\
\hline Microbial biomass & Fumigation extraction method & Vance et al. (1987) \\
\hline Dehydrogenase enzyme & Triphenyl Formazan (TPF) method & Casida et al. (1965) \\
\hline Phosphatase enzyme & p-nitrophenyl phosphate method & Tabatabi and Bremner (1969) \\
\hline Urease enzyme & NHH-N Distillation $_{4}$ & Bremner and Keeney (1966) \\
\hline
\end{tabular}

The recorded data were subjected to statistical analysis using the analysis of variance technique for randomized block design as suggested by Panse and Sukhame (1967) ${ }^{[6]}$.

\section{Result and Discussion}

The pooled data of results obtained from the present investigation on microbial load, soil microbial biomass and enzyme activity are presented in Table 2 and 3 . The microbial population in soil showed similar trend at 90 DAS and at harvest stage of pigeonpea, The activity value depletion in harvest stage might be due to decreased in moisture content. In the present study, the obtained results are clearly indicated that the treatment applied with $\mathrm{T}_{4}: 150 \%$ RDF (with FYM @ $6 \mathrm{t} \mathrm{ha}^{-1}$ ) have recorded significantly highest population of bacteria (37.08 and $22.47 \times 10^{7} \mathrm{cfu} \mathrm{g}^{-1}$ ), fungi (26.19 and $\left.10.83 \times 10^{4} \mathrm{cfu} \mathrm{g}^{-1}\right)$ and actinomycetes (16.07 and $9.63 \times 10^{4}$ cfu $\mathrm{g}^{-1}$ ) at 90 DAS and at harvest stage of pigeonpea, respectively and was found on par with $\mathrm{T}_{7}$ : Soil test based $\mathrm{N} \pm$ $25 \%$ and $\mathrm{P} \pm 50 \%$ (36.44 and $21.70 \times 10^{7} \mathrm{cfu} \mathrm{g}^{-1}, 26.01$ and $10.53 \times 10^{4} \mathrm{cfu} \mathrm{g}^{-1}$ and 15.82 and $9.37 \times 10^{4} \mathrm{cfu}^{-1}$ ), respectively. The increment in population of bacteria, fungi and actinomycetes by higher level of fertilizer (ie., $150 \%$ RDF) and generally applied FYM (@6 tha ${ }^{-1}$ ) might be due to increasing levels of $\mathrm{N}$ and $\mathrm{P}$ which increases the biomass, root exudates and ultimately provides carbon and energy to the soil microbes resulting into multiplication of microbial population (Geethakumari and Shivashankar, 1991) ${ }^{[3]}$. Similar findings were reported by Chand et al. (2010) ${ }^{[2]}$.

Soil microbial biomass is a sound indicator of soil health since it regulates nutrient cycling and acts as a highly labile source of plant available nutrients. Comparison of different nutrient management approaches revealed that application of $150 \%$ RFD $\left(\mathrm{T}_{4}\right)$ resulted significantly higher soil microbial biomass carbon (277 and $261 \mu \mathrm{g} \mathrm{CO}_{2}-\mathrm{C} \mathrm{g}^{-1}$ soil for $24 \mathrm{hrs}$ ) at 90 DAS and at harvest stage of pigeonpea, respectively. There is increased in level of soil microbial biomass carbon with increased fertilizer level. The results aare in agreement with these reported by Gogoi et al. (2010) ${ }^{[4]}$.

The dehydrogenase, phosphatase and urease enzyme activity are indicators of the biological activity in soils. At 90 DAS and at harvest stage of pigeonpea, $\mathrm{T}_{4}: 150 \% \mathrm{RDF}$ recorded the higher dehydrogenase, phosphatase and urease activity of 21.09 and $15.73 \mu \mathrm{g}$ TPF g ${ }^{-1}$ soil for $24 \mathrm{hrs}, 69.37$ and $66.8 \mu \mathrm{g}$ PNP g ${ }^{-1}$ soil for $1 \mathrm{hr}$ and 170 and $161 \mu \mathrm{g} \mathrm{NH}_{4}-\mathrm{N} \mathrm{g}^{-1}$ soil for 2 hrs, respectively, being on par with $\mathrm{T}_{7}$ : Soil test based $\mathrm{N} \pm$ $25 \%$ and $\mathrm{P} \pm 50 \%$ (20.80 and $15.03 \mu \mathrm{g} \mathrm{TPF} \mathrm{g} \mathrm{g}^{-1}$ soil for $24 \mathrm{hrs}$, 67.70 and $66.17 \mu \mathrm{g}$ PNP g ${ }^{-1}$ soil for $1 \mathrm{hr}$ and 167 and $158 \mu \mathrm{g}$ $\mathrm{NH}_{4}-\mathrm{N} \mathrm{g}^{-1}$ soil for $2 \mathrm{hrs}$ ). The lower value of activity of dehydrogenase (11.09 and $5.49 \mu \mathrm{g}$ TPF $\mathrm{g}^{-1}$ soil for $24 \mathrm{hrs}$ ), phosphatase (48.82 and $46.37 \mu \mathrm{g}$ PNP g ${ }^{-1}$ soil for $1 \mathrm{hr}$ ) and urease (116 and $106 \mu \mathrm{g} \mathrm{NH}_{4}-\mathrm{N} \mathrm{g}^{-1}$ soil for $2 \mathrm{hrs}$ ) enzymes were noticed with absolute control $\left(\mathrm{T}_{1}\right)$. Similar results were reported by Geethakumari and Shivashankar (1991) ${ }^{[3]}$. Masto et al. (2006) ${ }^{[5]}$ found that enzyme activity was dependent on addition of number and amount of nutrient.

Thus cultivation of pigeonpea with the application of fertilizer dose according to $150 \%$ RDF with FYM approach is in better preposition for maintaining good soil health regarding to biological properties of soil under rainfed condition in Vertisols of North eastern dry zone of Karnataka.

Table 2: Soil microbial population in soil sample estimated at different growth stages of pigeonpea as influenced by different nutrient management approaches

\begin{tabular}{|c|c|c|c|c|c|c|c|c|}
\hline \multirow[t]{2}{*}{ Treatment } & \multicolumn{2}{|c|}{$\begin{array}{c}\text { Bacteria } \\
\left(10^{7} \text { cfu }^{-1}\right)\end{array}$} & \multicolumn{2}{|c|}{ Fungi $\left(10^{4} \mathrm{cfu} \mathrm{g}^{-1}\right)$} & \multicolumn{2}{|c|}{$\begin{array}{l}\text { Actinomycetes } \\
\left(10^{4} \text { cfu g }^{-1}\right)\end{array}$} & \multicolumn{2}{|c|}{$\begin{array}{c}\text { Biomass }\left(\mu \mathrm{CO}_{2}-\mathrm{C} \mathrm{g}^{-1}\right. \\
\text { soil for } 24 \mathrm{hrs})\end{array}$} \\
\hline & 90 DAS & At harvest & 90 DAS & At harvest & 90 DAS & At harvest & 90 DAS & At harvest \\
\hline $\mathrm{T}_{1}$ : Absolute control & 21.51 & 13.92 & 15.34 & 4.85 & 8.46 & 3.68 & 216 & 199 \\
\hline $\mathrm{T}_{2}$ : Farmers practice & 27.30 & 16.08 & 21.04 & 7.19 & 12.78 & 6.82 & 246 & 223 \\
\hline $\mathrm{T}_{3}: \mathrm{RDF}$ & 30.95 & 18.17 & 23.63 & 9.08 & 14.09 & 7.84 & 257 & 243 \\
\hline $\mathrm{T}_{4}: 150 \% \mathrm{RDF}$ & 37.08 & 22.47 & 26.19 & 10.83 & 16.07 & 9.63 & 277 & 261 \\
\hline T5: STL method & 33.79 & 19.09 & 25.10 & 9.64 & 15.02 & 8.56 & 268 & 248 \\
\hline $\mathrm{T}_{6}:$ Soil Test based NP $\pm 25 \%$ & 35.88 & 20.35 & 25.46 & 10.10 & 15.31 & 8.82 & 272 & 252 \\
\hline $\mathrm{T}_{7}:$ Soil Test based $\mathrm{N} \pm 25 \%$ and $\mathrm{P} \pm 50 \%$ & 36.44 & 21.70 & 26.01 & 10.53 & 15.82 & 9.37 & 274 & 255 \\
\hline T8: STCR approach (Targeted yield: $15 \mathrm{q} \mathrm{ha}^{-1}$ ) & 28.16 & 16.32 & 22.93 & 7.84 & 13.13 & 7.17 & 248 & 236 \\
\hline $\mathrm{T}_{9}$ : STCR approach (Targeted yield: $18 \mathrm{q} \mathrm{ha}^{-1}$ ) & 29.99 & 17.73 & 23.51 & 8.81 & 13.66 & 7.53 & 255 & 239 \\
\hline $\mathrm{T}_{10}:$ STCR approach (Targeted yield: $20 \mathrm{q} \mathrm{ha}^{-1}$ ) & 32.52 & 18.91 & 24.11 & 9.28 & 14.58 & 8.37 & 267 & 245 \\
\hline S. Em. \pm & 0.47 & 0.41 & 0.52 & 0.20 & 0.31 & 0.18 & 5.67 & 5.27 \\
\hline C.D. at 5\% & 1.41 & 1.22 & 1.53 & 0.61 & 0.93 & 0.52 & 16.85 & 15.66 \\
\hline
\end{tabular}

Note: FYM @ $6 \mathrm{t} \mathrm{ha}^{-1}$ and deficient nutrients were applied for all treatments except $\mathrm{T}_{1}$ 
Table 3: Soil enzymatic activity in soil sample collected at different growth stages of pigeonpea as influenced by different nutrient management approaches

\begin{tabular}{|c|c|c|c|c|c|c|}
\hline \multirow[t]{2}{*}{ Treatment } & \multicolumn{2}{|c|}{$\begin{array}{c}\text { Dehydrogenase activity } \\
\left(\mu \mathrm{g} \text { TPF } \mathrm{g}^{-1} \text { soil for } 24 \mathrm{hrs}\right)\end{array}$} & \multicolumn{2}{|c|}{$\begin{array}{c}\text { Phosphatase activity } \\
\left(\mu \mathrm{g} \mathrm{PNP} \mathrm{g}^{-1} \text { soil for } 1 \mathrm{hr}\right)\end{array}$} & \multicolumn{2}{|c|}{$\begin{array}{c}\text { Urease activity }\left(\mu \mathrm{g} \mathrm{NH} 4-\mathrm{N} \mathrm{g}^{-1}\right. \\
\text { soil for } 2 \mathrm{hrs})\end{array}$} \\
\hline & 90 DAS & At harvest & 90 DAS & At harvest & 90 DAS & At harvest \\
\hline $\mathrm{T}_{1}$ : Absolute control & 11.09 & 5.49 & 48.82 & 46.37 & 116 & 106 \\
\hline $\mathrm{T}_{2}$ : Farmers practice & 16.03 & 12.02 & 60.60 & 55.80 & 129 & 121 \\
\hline $\mathrm{T}_{3}: \mathrm{RDF}$ & 17.52 & 13.53 & 63.76 & 59.50 & 144 & 136 \\
\hline $\mathrm{T}_{4}: 150 \% \mathrm{RDF}$ & 21.09 & 15.73 & 69.37 & 66.81 & 170 & 161 \\
\hline T5: STL method & 19.58 & 14.39 & 64.93 & 62.09 & 157 & 149 \\
\hline $\mathrm{T}_{6}:$ Soil Test based NP $\pm 25 \%$ & 20.44 & 14.81 & 66.56 & 64.78 & 164 & 153 \\
\hline $\mathrm{T}_{7}:$ Soil Test based $\mathrm{N} \pm 25 \%$ and $\mathrm{P} \pm 50 \%$ & 20.80 & 15.03 & 67.70 & 66.17 & 167 & 158 \\
\hline T8: STCR approach (Targeted yield: $15 \mathrm{q} \mathrm{ha}^{-1}$ ) & 16.46 & 12.67 & 61.16 & 56.17 & 132 & 127 \\
\hline $\mathrm{T}_{9}:$ STCR approach (Targeted yield: $18 \mathrm{q} \mathrm{ha}^{-1}$ ) & 17.31 & 13.30 & 62.42 & 58.10 & 141 & 132 \\
\hline $\mathrm{T}_{10}$ : STCR approach (Targeted yield: $20 \mathrm{q} \mathrm{ha}^{-1}$ ) & 19.17 & 14.12 & 64.57 & 61.08 & 152 & 144 \\
\hline S. Em. \pm & 0.40 & 0.29 & 1.39 & 1.32 & 3.26 & 3.07 \\
\hline C.D. at $5 \%$ & 1.19 & 0.88 & 4.13 & 3.92 & 9.70 & 9.12 \\
\hline
\end{tabular}

\section{References}

1. Anonymous. Agriculture statistics at glance. Ministry of Agriculture and Farmer welfare, Government of India. New Delhi, 2015.

2. Chand S, Somani LL, Bhandari SC. Effect of fertilizer, farmyard manure (FYM) and biofertilizer on the population of Azotobacter and phosphate solubilising bacteria (PSB) in the soil. J Indian Soc. Soil Sci. 2010; 58(4):460-463.

3. Geethakumari VL, Shivashankar K. Studies on organic amendment and $\mathrm{CO}_{2}$ enrichment in ragi/soybean intercropping systems. Indian J Agro. 1991; 36:202-206.

4. Gogoi B, Barua NG, Baruah TC. Effect of integrated supply of nutrients on soil microbial biomass carbon in an Inceptisol of Assam. J Indian Soc. Soil Sci. 2010; 58(2):241-244.

5. Masto RE, Chhonkar PK, Singh D, Patra AK. Changes in soil biological and biochemical characteristics in a longterm field trial on a sub-tropical Inceptisol. Soil Bio. Bioc. 2006; 38:1577-1582.

6. Panse VG, Sukhatme PV. Statistical Methods for Agricultural Workers, ICAR publications, New Delhi, 1967, pp. 32. 